\title{
Purple Drank, Sizurp, and Lean: Hip-Hop Music and Codeine Use, A Call to Action for Public Health Educators
}

\author{
Naa-Solo Tettey ${ }^{1}$, Khizar Siddiqui ${ }^{1}$, Hasmin Llamoca ${ }^{1}$, Steven Nagamine ${ }^{1}$ \& Soomin Ahn ${ }^{1}$ \\ ${ }^{1}$ Department of Public Health, William Paterson University, Wayne, NJ, United States \\ Correspondence: Naa-Solo Tettey, Department of Public Health, William Paterson University, Wayne, NJ, \\ United States.
}

Received: January 6, 2020

Accepted: February 13, $2020 \quad$ Online Published: February 26, 2020

doi:10.5539/ijps.v12n1p42

URL: https://doi.org/10.5539/ijps.v12n1p42

\begin{abstract}
The opioid epidemic continues to create various public health challenges in the United States. Non-medical use of opioids is increasing at alarming rates and has been glamorized through popular media including television, movies, and music. One particular area of concern is the promotion in hip-hop music of the use of codeine mixed with promethazine, also known as "lean." In recent years, this drug combination has proven to be lethal with many hip-hop artists dying from overdoses involving lean while others have suffered from adverse health consequences such as seizures. Because the hip-hop music audience is primarily comprised of youth who often represent vulnerable and social disadvantaged populations, it is imperative to develop interventions that counteract the negative influence of such songs. The purpose of this study is to review the lyrics of popular hip-hop songs that mention lean and determine common themes within these songs that can be used to guide future interventions. To identify these themes, the lyrics of 40 hip-hop songs were evaluated by four independent coders. 8 themes emerged and the frequency in which these themes appeared in the song lyrics was calculated. These themes are the use of lean with another drug (37.5\%), the general mention of lean without a connection to a behavior, activity, emotion, or another substance $(27.5 \%)$, the use of lean during sexual activity $(15 \%)$, the use of lean with soda $(12.5 \%)$, the use of lean to help with sleep (5\%), the use of lean as an alternative to alcohol (5\%), the use of lean while driving $(5 \%)$, and the use of lean for mental distress (5\%). These results demonstrate that there are various aspects of lean use that require further investigation. Furthermore, these results serve as a call to action for public health practitioners to create culturally tailored interventions to address this issue.
\end{abstract}

Keywords: opioid, hip-hop, lean, health disparities, addiction

\section{Introduction}

The opioid crisis is one of the major public health issues affecting the United States. Of the 70,200 drug overdose deaths in 2017, 68\% involved an opioid (Centers for Disease Control and Prevention [CDC], 2019). The rate of opioid deaths in 2017 from prescription and illegal opioids was 6 times as high as the number of overdose deaths in 1999 (CDC, 2019). Approximately 130 Americans die daily from an opioid related overdose (CDC, 2019). The alarming rates of overdose deaths and the increase in the use of prescription opioid drugs for non-medical reasons has left the public health community scrambling to understand this problem and create sustainable, effective solutions (McCabe et al., 2017). Of particular concern is the increased use of opioids for non-medical reasons by adolescents (McCabe et al., 2017). Although the opioid epidemic effects all facets of American society, vulnerable populations that are socially disadvantaged are disproportionately impacted (Han et al., 2017). In 2014, a total of 10.3 million people reported using prescription opioids for non-medical purposes. In 2017, this number increased to an estimated 18 million people (Center for Behavioral Health Statistics and Quality, 2018). Although there are various explanations for the current trends in opioid use, one area that has not received as much attention is the role of music. The promotion of illicit drug use can be found in many genres of media, especially music (Gruber, Thau, Hill, Fisher, \& Grube, 2005; Harakeh \& Ter Bogt, 2018)). Hip-hop music is one of the more popular and influential genres of music today. In recent years, there has been an increase in the promotion and glamorization of opioid drug use in hip-hop songs (Peters, 2003). In addition, numerous hip-hop artists have died from opioid drug overdoses or suffered adverse side effects such as seizures. Public health practitioners must work to understand the relationship between hip-hop and increased opioid use. The purpose of 
this study is to assess hip-hop lyrics that promote opioid use to determine themes that can aid in developing interventions tailored specifically for this population.

The reach of hip-hop music is global and, in many respects, dictates various aspects of cultural trends including speech, dress, and dance. Although the origins of hip-hop music were meant for community uplifting and positive social change, there has been a shift for some artists in a direction that supports lyrics which are harmful for its listeners (Miller, Hodge, Coleman, \& Chaney, 2014). One such trend is the increased emphasis on the use of harmful drugs (Beumont-Thomas, 2017). This new direction has become so embedded in the culture of hip-hop that it has led some artists to believe their success depends on the promotion of negative behaviors including some form of drug use (Smiley, 2017).

In addition to alcohol and marijuana references, hip-hop lyrics now mention more dangerous and addictive substances including codeine, ecstasy, Percocet, oxycodone, and Xanax. Many of these substances have been given alternate names which may make them more appealing to users. One example of this is "lean." Lean is a hip-hop derived term for a popular drink that contains promethazine and codeine. The term lean originates from Houston, Texas, where the lean phenomenon is attributed, and is meant to signify the posture that users have when they are intoxicated (Agnich, Stogner, Miller, \& Marcum, 2013). Some rappers such as Yung Lean, Joey Purp, and Lil Xan, have even created their stage names based on these drugs. In addition, there is an entire subgenre of hip-hop known as "sound cloud rap" that specifically focuses on the use of Xanax and lean (Beaumont-Thomas, 2017).

Codeine is a class of opioid drug that is found in prescription cough medicines and is highly addictive (VanHout, Hora, Santlal, Rich, \& Bergin, 2018). Misuse of codeine can lead to various adverse health outcomes including extreme fatigue, skin rashes, distorted vision and shortness of breath. Other chronic side effects are nausea, constipation, liver, bowel and kidney failure, anemia, seizures, ulcers and swollen stomach (VanHout, Hora, Santlal, Rich, \& Bergin, 2018). Despite these health consequences, the rate of codeine misuse continues to increase.

To prepare lean, a mixture of cough syrup containing codeine and promethazine is mixed with hard candies such as Jolly Ranchers, and soda, usually sprite. Sometimes this mixture may also contain alcohol. Other names for lean in hip-hop music include "sizurp" and "purple drank." Users often feel more relaxed with a heightened sense of euphoria when consuming this drink. Large doses of lean can replicate the high that is produced when using heroin. However, lean can also lead to various physical and psychological health problems. Lean has been highly promoted and glorified among urban black males, but users of lean come from varied backgrounds (Agnich, Stogner, Miller, \& Marcum, 2013). Rappers such as Lil Peep and Mac Miller, who are Caucasian and both suffered from drug overdoses, were codeine users and promoted this drug in their music. In addition to premature deaths, the negative health effects of codeine have been demonstrated in rappers such as Lil Wayne who experienced codeine induced seizures.

Understanding the prevalence of codeine use resulting from the exposure to hip-hop lyrics is a phenomenon that has not been studied and may prove too difficult to fully research. However, an in-depth analysis of hip-hop lyrics that promote codeine use could offer insight into the reasons why the drug is being used, the messages being given to users about the effects of the drugs, and the consequences of using these drugs.

\section{Methods}

A content analysis was conducted using the lyrics of hip-hop artists who are known to promote codeine use in their music. The artists were selected from an article titled " 40 of The Best Hip Hop Songs That Mention Lean" which was published by XXL a reputable hip hop magazine (Rys, 2014). The actual list only contains 39 songs. As a result, one more song was added titled "Sippin on Syrup" by the rap group Three 6 Mafia. This particular song was selected from an article titled "A History of Sizzurp in Song" (Lee, 2013), because it was the first mainstream song that focused on the use of lean. For both articles, the particular lyrics representing lean use were included. Four student research assistants were trained in the protocol as coders. First, the coders independently reviewed the selected lyrics for the 40 songs and described how the use of codeine was being described. Next, the coders met together with the lead researcher to determine if there were common themes demonstrated in these results. Based on the initial analysis by the coders, eight themes were established. These themes are general use of lean (not associated with any other activity, behavior, substance, or emotional state), use of lean while driving, use of lean during sexual activity, use of lean to help with sleep, use of lean for mental distress, use of lean as an alternative to alcohol, use of lean as a recreational drink combined with soda, and the use of lean with another drug (see Table 1). Once these themes were established, coders reviewed the lyrics a second time to determine which lyrics matched with the particular themes. The frequency of each theme was then calculated. 
Table 1. Content Analysis of the use of Lean in Selected Hip-hop Song Lyrics

\begin{tabular}{|c|c|c|c|c|}
\hline & Artist & Song Name & Lyric (s) & Theme (s) \\
\hline 1 & Young Thug & Two Cups Stuffed & $\begin{array}{c}\text { "L-E-A-N-I-N-G/Lean, } \\
\text { lean, lean, lean, lean } \\
\text { lean lean", } \\
\text { "Uno dos cups } \\
\text { stuffed!/Uno dos cups } \\
\text { stuffed!/Uno dos cups } \\
\text { stuffed!/Uno dos cups } \\
\text { stuffed!" }\end{array}$ & $\begin{array}{c}\text { General mention of } \\
\text { lean }\end{array}$ \\
\hline 2 & Migos & Hannah Montana & $\begin{array}{l}\text { "Hannah Montana I'm } \\
\text { sellin' them bricks out } \\
\text { the Phantom/Got } \\
\text { Hannah Montana I'm } \\
\text { drinking the lean out the } \\
\text { Fanta" }\end{array}$ & $\begin{array}{c}\text { Lean used in } \\
\text { combination with soda }\end{array}$ \\
\hline 3 & 2 Chainz & Gasolean & $\begin{array}{l}\text { "Yeah, I'm on that } \\
\text { gas/And yeah, I'm on } \\
\text { that lean/We mix it all } \\
\text { together and we call it } \\
\text { gasolean" } \\
\text { "gas" is another word } \\
\text { for marijuana }\end{array}$ & $\begin{array}{l}\text { Lean used with } \\
\text { another drug }\end{array}$ \\
\hline 4 & Ab-soul & Thorns and Horns & $\begin{array}{l}\text { "I got some lean up in } \\
\text { my Sprite/I call it the } \\
\text { Jesus Juice/What would } \\
\text { Jesus do? Whoo!" }\end{array}$ & $\begin{array}{c}\text { Lean used in } \\
\text { combination with soda }\end{array}$ \\
\hline 5 & French Montana & Work & $\begin{array}{l}\text { Baby don't pray for me, } \\
\text { pray for the weak/I'm } \\
\text { drinkin' lean, it help me } \\
\text { sleep/Illuminati? I'm } \\
\text { from the streets/Never } \\
\text { sold my body, we takin' } \\
\text { bodies" }\end{array}$ & $\begin{array}{l}\text { Lean to help with } \\
\text { sleep }\end{array}$ \\
\hline 6 & Chief Keef & Ight Doe & $\begin{array}{l}\text { "I don't drink liquor but } \\
\text { I sip lean, though/Bitch } \\
\text { I payed } 600 \text { for this pint, } \\
\text { though" }\end{array}$ & $\begin{array}{c}\text { Lean as an alternative } \\
\text { to alcohol }\end{array}$ \\
\hline 7 & Danny Brown & Float On & $\begin{array}{l}\text { "Can't get a wink 'less } \\
\text { I'm leaning off of } \\
\text { syrup/Dreaming of my }\end{array}$ & $\begin{array}{c}\text { 1. Lean to help } \\
\text { with sleep }\end{array}$ \\
\hline
\end{tabular}


8

Fat Trel

Fresh

Flatbush Zombies

Fredo Santana

10

11

12

13

Juicy J

Gucci Mane

14

ASAP Rocky
I Heard

Drug Parade

Like Woah

Shit

Trippy

Servin' Lean past like a nightmare so

$$
\text { I wake up" }
$$

2. Lean to help with mental distress

General use of lean dont fight/Drinkin' lean finna catch me a flight" "Join the regime/Whole sheet of LSD for the team/Eyes low, sour $\operatorname{dies}[\mathrm{el}] /$ She sippin' that Jeremy Lean"

"Man I smoke a lot of O's/Sip lean and I fuck a lot of hoes/Got a big ass gun (woah)/And that bitch gonna blow like woah" “"My ambitions as a General use of lean rider/Sippin' on lean getting higher/Nigga I'm a codeine buyer/No you not a foreign whip driver"

"Hit the weed man, tell him that I need a Lean used with another drug. bag/Wake up every morning and I take a drag/Take the blunt, dip it in the lean then I laugh/In your baby mama ear and I'm gonna smash"

"She suck the dick like no teeth/She on her knees like she got no knees/It's three and we ain't got no lean/Gotta call somebody need more PT"

"Since my early teens, I General use of lean been sitting clean, mixing, sipping lean/With the leader, up 
15

16

17

18

19

20

21

Jarren Benton Lean

Juicy J

Kevin Gates

4:30am

Kid Ink

Iz U Down

King Louie

Kirko Bangz

Drank in my Cup

Lil Bibby in illy beamers, that's a

misdemeanor, FEMA"

"You put the codeine in the Sprite/And then you mix it all up/Then you sip it slow/That's how them killas get fucked up/We call it Lean"

"Cali weed in a dutch/Purple lean in my cup/Smokin' while I'm drivin'/Nigga we be fucked up"

Gladiators on deck/Drug user, don't drink sprite/And when I do, it ain't pink sprite/A lot of lean, it's purple"

"Just pour me up, higher/I'm sippin' lean like I'm on a fuckin' diet/L.A. nigga, 'bout to start a fuckin' riot/Why you tryna deny it?" "Now I don't know about you, cuz/My hoes they drugs/Pop a bean, pourin' lean/My hoes they do drugs/Now I don't know about you, cuz/My hoes they drugs/Poppin' Molly, rolling weed up" "I'm in her head like Maybelline/H-Town so I'm made for lean/I'm in her soul, I make her scream/I don't ride the toll, don't pay the change"

"Ain't enough smoke/Ain't enough lean/You ain't did what I
Use of lean with soda

Lean used with another drug.

Use of lean while driving

Use of lean with soda

General use of lean.

1. Use of lean during sex

2. Use of lean with another drug

Use of lean during sex

Use for mental distress 
22

23

24

25

26

27

\section{Lil Debbie}

Future

Lil Wayne

Mac Miller

Souljah Boy

Zan with that Lean

Juicy J
2 Cups

Dirty Sprite

Bitches and Bottles

Loud

uicy J Can't $\mathrm{did} /$ You ain't seen what

I've seen"

"All I need is two cups of some lean/And a bad bitch just to roll up my weed/Bended through the city with the gold on my teeth/Probably in the scrape with the 4's underneath"

"One, two cups keep my ice cool/Three or four zips have me leaning like a fool/Purple Sprite on top of ice/I'm rocking ice I'm dirty sprite" "Man I'm on that lean/Liquor for the bitches/Who fuckin' wit me?/All I hear is crickets"

"Hear that Jerm beat banging with a glass of lean/When I went to every high school class would be/Tryna fuck the female faculty" "Zan with that lean/Soulja Boy be clean/True Religion jeans/Shit you never seen/Fresh up on that scene"

"Lean overflowing like New Orleans' broken levies/No relationship with hoes, I just want that Becky/I'm bout my money, I gets my fetti/Street nigga, North Memphis, bitch I still rep it" Use of lean with soda

\section{Use of lean while} driving

Use of lean with other drugs$$
\text { Use of lean with soda }
$$ 
28

29

30

31

32

33

34
Migos

Mike Jones

Nas

Que

Future

Schoolboy Q

Souljah Boy
Break the Bank

Ounces

Still Tippin

Hip Hop

Time

U.O.E.N.O.

Molly with Lean team $/ \mathrm{I}$ be on

lean/Sipping on

purp/Me, my nigga

Dean"

"Money taller than mountains/Drinking

lean out of damn water

fountains"

"My gasoline always supreme/Got do-do to burn with a pint of lean/It takes grinding to be a King"

"She slowed me down and had me guzzling on cups of lean/She's a middle-aged cougar, showing youngins the dream" "Might pop Molly, make the time move forward/Might sip lean so the time move slower"

"This a thousand dollar pair of shoes and you don't even know it

This a thousand dollar cup of lean and you don't even know it This a half a million dollar car, you don't even know it." "Hid the gun in the trees, arrest me by the court/I just wanna smoke weed and sip lean by the quart" "Molly with that lean, rolling through the streets/Molly with that lean, bitch I do my thing"
General Use of Lean

Use of lean with another drug

Use of lean during sex

Use of lean with another drug

General use of lean

Use of lean with another drug

Use of lean with another drug 


\begin{tabular}{|c|c|c|c|c|}
\hline 35 & Lil Wayne & Just Lean & $\begin{array}{l}\text { "Bad bitch, good weed, } \\
\text { purple drank, just } \\
\text { lean/Now just } \\
\text { lean/Yeah/Just lean/Tell } \\
\text { a bitch lean" }\end{array}$ & $\begin{array}{l}\text { Use of lean with } \\
\text { another drug }\end{array}$ \\
\hline 36 & Pimp C & Big Pimpin & $\begin{array}{l}\text { "Smoking out, pouring } \\
\text { up/Keep that lean up in } \\
\text { my cup/All my car got } \\
\text { leather and wood/In my } \\
\text { hood we call it buck" }\end{array}$ & $\begin{array}{l}\text { Use of lean with } \\
\text { another drug }\end{array}$ \\
\hline 37 & Vic Mensa & Tweakin & $\begin{array}{l}\text { "And I think it's that } \\
\text { weed got me, I'm } \\
\text { tweakin'/Maybe that } \\
\text { lean got me, I'm } \\
\text { tweakin"' }\end{array}$ & $\begin{array}{l}\text { Use of lean with } \\
\text { another drug }\end{array}$ \\
\hline 38 & Wale & $\begin{array}{l}\text { The Chicago } \\
\text { Falcon }\end{array}$ & $\begin{array}{l}\text { "Eye of the tiger, no I'm } \\
\text { never lying/Seven shots } \\
\text { down, I'm on that lean } \\
\text { like a diet" }\end{array}$ & General use of lean \\
\hline 39 & YG & My Nigga & $\begin{array}{l}\text { "You lookin' for some } \\
\text { lean, lemme call my } \\
\text { nigga/He sell it for the } \\
\text { high, I need all mines, } \\
\text { nigga" }\end{array}$ & General use of lean \\
\hline 40 & Three 6 Mafia & $\begin{array}{l}\text { Sippin on Some } \\
\text { Syrup }\end{array}$ & $\begin{array}{l}\text { "Sipping and dipping } \\
\text { and tripping, man I'm } \\
\text { bout all out. Sippin' on } \\
\text { some sizurp, sip, sippin' } \\
\text { on some, sip" }\end{array}$ & $\begin{array}{l}\text { Use of lean with } \\
\text { another drug }\end{array}$ \\
\hline
\end{tabular}

\section{Results}

The total sample of 40 songs yielded 8 themes. Some songs illustrated more than one theme (See Table 2). The theme that was most prevalent in the songs was the use of lean with another drug with $37.5 \%$ of the songs. The next theme was general use of the term lean with $27.5 \%$ of the songs just mentioning lean without the connecting it with any other behavior, activity, substance, or emotional state. Next, was use of lean during sexual activity with $15 \%$. Followed by the recreational use of lean with soda with $12.5 \%$ of the songs. Use of lean as an alternative to alcohol, use of lean while driving, use of lean for mental distress, and use of lean to help with sleep, all independently represented 5\% each of the total themes (See Table 2). 
Table 2. Frequency of Themes Related to Lean in Hip Hop Song Lyrics $(n=40)$

\begin{tabular}{lcc}
\hline & Song Theme & Frequency \\
\hline 1. & Use of lean with another drug & $37.5 \%$ \\
2. & General Use or Mention of the Term Lean (not connected with any other behavior, & $27.5 \%$ \\
& substance, or emotional state. & \\
3. & Use of lean during sexual activity & $15 \%$ \\
4. & Use of lean with soda & $12.5 \%$ \\
5. & Use of lean to help with sleep & $5 \%$ \\
6. & Use of lean as an alternative to alcohol & $5 \%$ \\
7. & Use of lean while driving & $5 \%$ \\
8. & Use of lean for mental distress & $5 \%$ \\
\hline
\end{tabular}

\section{Discussion}

The use of codeine for recreational purposes in the form of lean is a public health problem that requires greater attention. However, any efforts to improve this issue must first have a solid understanding of the reasons for the use of this drug. One area that can provide further insight is hip-hop music. Through this content analysis of hip-hop song lyrics that mention codeine, it is clear that rappers have been expressing their desire for using this drug along with the reasons why this desire continues to increase even in the face of deadly consequences. The largest theme represented in the song lyrics is the use of lean with other drugs. From a public health standpoint, this practice is quite dangerous because it increases the likelihood of overdose or health complications (American Addiction Centers, 2019). The next most prevalent theme is the general mention of the word lean in these songs. Codeine is a very dangerous and highly addictive drug. Normalizing its recreational use by calling it lean and casually mentioning it in song lyrics may make it more appealing and increase use among listeners (Advanced Recovery Systems, 2019). The use of lean while engaging in sexual activity is also of great concern. Inhibitions are decreased and poor health decisions are more likely to be made when under the influence of drugs or alcohol (Cooper, 2006; Raj, Saitz, Cheng, Winter, \& Samet, 2007). The use of lean as an alternative to alcohol is something that needs to be explored further. The lyrics that represent this trend tend to frame it as lean being less dangerous than alcohol and therefore being a good choice. Chief Keef writes in his song titled "Ight Doe," "I don't drink liquor but I drink lean, tho." Although there are ongoing debates regarding the hierarchy of danger as it relates to substance use, the misconception cannot be made that one harmful substance is better to use than another. In addition, the theme of lean mixed with soda may also create a false perception that codeine is meant for recreational use. The combination of soda and candy with lean may create a lure for younger users and decrease the feelings of danger that should be associated with using these substances. The use of lean while driving is also a disturbing trend found in some of these lyrics. Driving while impaired in any way is both a danger to the driver and others who they come in contact with. The final themes that were assessed in this study highlighted the use of lean for mental and emotional states including the inability to sleep and coping with mental distress. This theme is important to note because there is emerging research regarding the unspoken depression, anxiety, PTSD, and trauma experienced by some listeners of hip-hop music (Addiction Recovery Systems, 2019). In his song titled "Stressin,” rapper Lil Bibby writes, “Ain't enough smoke. Ain't enough lean. You ain't did what I did. You ain't seen what I seen." Instead of lean and other unhealthy coping strategies being promoted among this group, healthier options and increased resources should be made available. Furthermore, hip-hop lyrics should bring more awareness to the mental state of many hip-hop artists and those who listen to their music.

One limitation of this study is that it only assessed 40 songs. Future studies should conduct a more in-depth analysis to fully understand the themes that are being represented. Another limitation of this study is that the songs selected did not extend beyond 2014. In the time since 2014, more songs have been made that mention the use of lean and perhaps new drugs or additional themes. Another limitation of this study is that there is no data from actual lean users to confirm the connection between their lean use and the hip-hop lyrics. In addition to the role of hip-hop lyrics in promoting lean use, future studies could focus on the lived experience of lean users to develop a better profile of this group. 


\section{Conclusions}

The opioid crisis that is impacting the United States has many contributing factors, with media being one that may not be receiving enough attention. Media is a powerful tool for promoting both healthy and unhealthy ideas and behaviors. High school students surveyed shared that media modeling increased the popularity of codeine and promethazine hydrochloride cough syrup (Peters et al., 2003). Furthermore, the theme of codeine use is highly prevalent in hip-hop music, as demonstrated in this study. The connection between drug use and hip-hop music is not new. However, the evolution of this relationship has taken a negative turn. Hip-hop music and other forms of media have a tendency to glamorize drug use without focusing on the consequences. Many people are unaware of negative consequences of using substances like lean (VanHout et al., 2018). It is important to note that there are numerous hip-hop artists who do not promote or support drug use such as Chance the Rapper and LeCrae (Advanced Recovery Systems, 2019). There is a unique opportunity for public health educators to join with such artists and others who are on the frontlines of this movement to develop culturally tailored interventions for this target population.

\section{References}

Advanced Recovery Systems. (2019). Rap Music and Substance Use: Addiction and Mental Health. Retrieved from: https://www.drugrehab.com/featured/substance-use-and-rap-music/

Agnich, L., Stogner, J., Miller, B. \& Marcum, C. (2013). Purple drank prevalence and characteristics of misusers of codeine cough syrup mixtures. Addictive Behaviors, (38), 2445-2449. https://doi.org/10.1016/j.addbeh.2013.03.020.

American Addiction Centers (2019). The Dangers of Mixing Alcohol and Codeine. Retrieved from: https://americanaddictioncenters.org/codeine-addiction/dangers-of-mixing-with-alcohol.

Beaumont-Thomas, B. (2017). The Death of Lil Peep: How the US Prescription Drug Epidemic Is Changing Hip-Hop. The Guardian, Guardian News and Media, 16 Nov. 2017, www.theguardian.com/music/2017/nov/16/death-lil-peep-us-prescription-drugs-epidemic-hip-hop-rapper.

Center for Behavioral Health Statistics and Quality (2019). Results from the 2017 National Survey on Drug Use and Health: Detailed Tables. Rockville (MD): SAMHSA; 2018.

Centers for Disease Control and Prevention (CDC). (2019). Understanding the Epidemic. Retrieved from: https://www.cdc.gov/drugoverdose/epidemic/index.html

Cooper, M.L. (2006). Does Drinking Promote Risky Sexual Behavior? A Complex Answer to a Simple Question. Current Directions in Psychological Science, (15), 19-23.

Gruber, E.L., Thau, H.M., Hill, D.L., Fisher, D.A. \& Grube, J.W. (2005). Alcohol, tobacco and illicit substances in music videos. $J$ Adolesc Health, 37(1), 81- 83. https://doi.org/10.1016/j.jadohealth.2004.02.034

Han B, Compton WM, Blanco C, Crane E, Lee J \& Jones CM. (2015). Prescription Opioid Use, Misuse, and Use Disorders in U.S. Adults: National Survey on Drug Use and Health. Ann Intern Med, 167(5), 293. https://doi.org/10.7326/M17-0865

Lee, C. (2013). A History of Sizzurp in Song. March 23, 2013. The Los Angeles Times. https://www.latimes.com/entertainment/music/la-xpm-2013-mar-23-la-et-ms-lil-wayne-sizzurp-codeine 20130321-story.html

Mccabe, S. E., West, B. T., Veliz, P., mccabe, V. V., Stoddard, S. A. \& Boyd, C. J. (2017). Trends in Medical and Nonmedical Use of Prescription Opioids Among US Adolescents: 1976-2015. Pediatrics, 139(4). https://doi.org/10.1542/peds.2016-2387

Miller, M., Hodge, D. W., Coleman, J. \& Chaney, C. D. (2014). The hip in hip hop: Toward a discipline of hip hop studies. The Journal of Hip-Hop Studies, 1(1), 6-12. Retrieved from https://ezproxy.wpunj.edu/login?url=https://search.proquest.com/docview/1513811091?accountid=15101

Peters, R. J., Kelder, S. H., Markham, C. M., Yacoubian, G. S., Peters, L. A. \& Ellis, A. (2003). Beliefs and social norms about codeine and promethazine hydrochloride cough syrup (CPHCS) onset and perceived addiction among urban Houstonian adolescents: An addiction trend in the city of lean. Journal of Drug Education, 33(4), 415-425.

Raj, A., Saitz, R., Cheng, D.M., Winter, M. \& Samet, J.H. (2007). Associations between alcohol, heroin and cocaine use and high risk sexual behaviors among detoxification patients. Am J Drug Alcohol Abuse, 33, $169-178$. 
Rys, D. (2014). 40 of the Best Hip Hop Songs that Mention Lean. XXL May 8, 2014 https://www.xxlmag.com/news/2014/05/40-hip-hop-songs-lean-lyrics/

Smiley, J. C. (2017). Addict Rap? The Shift from Drug Distributor to Drug Consumer in Hip Hop. The Journal of Hip Hop Studies, 4(1), 1-149.

VanHout M.C., Horan, A., Santlal, K., Rich E. \& Bergin M. (2018). 'Codeine is my companion': misuse and dependence on codeine containing medicines in Ireland. Irish Journal of Psychological Medicine, 35, 275-288.

Zeena Harakeh \& Tom F.M. Ter Bogt (2018). The Effect of Rap/Hip-Hop Music on Young Adult Smoking: An

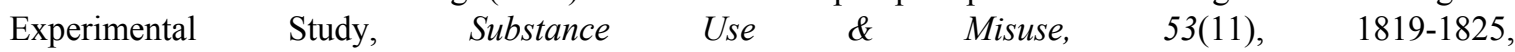
https://doi.org/10.1080/10826084.2018.1436565

\section{Copyrights}

Copyright for this article is retained by the author(s), with first publication rights granted to the journal.

This is an open-access article distributed under the terms and conditions of the Creative Commons Attribution license (http://creativecommons.org/licenses/by/4.0/). 